\title{
Thesis Writing Model of Art Practice
}

\author{
Indro Moerdisuroso \& Zaitun Y.A. Kherid
}

Universitas Negeri Jakarta, Jalan Rawamangun Muka, Jakarta 13220

E-mail: indro@unj.ac.id; eza_kherid@unj.ac.id

\begin{abstract}
The result of this study is contributed to improving the academic thinking of art practice students, especially in the writing of the undergraduate thesis. The problem is about a system of academic thinking as reflected in the thesis guidebook. Students' academic thinking in thesis writing is guided by a manual book published by a local institution. The case in this study is the thesis guidebook of art practice in an art study program. In this book has no explicit explanation on method and analysis aspects. Whereas both of these aspects are precisely the essence of academic thinking, that is research-based thinking. This fact encourages a study of thesis writing model of art practice, particularly on methods and analysis aspects. This study implements a Research and Development (R\&D) approach and mixed methods. The model will propose Teikmanis' typology of art-related research, such as practice-led research, research-led practice, and artistic research. It also adapted Barrett's structure of art education, which consisted of conceptual, operational and synthesis aspects. The conclusion of the study showed that the participants were able to arrange a thesis based on this model.
\end{abstract}

Keywords: thesis writing, art practice, analysis, guidebook

\section{Model Penulisan Tesis Praktik Seni}

\section{ABSTRAK}

Hasil penelitian ini dikontribusikan untuk meningkatkan pemikiran akademik mahasiswa praktik seni, khususnya dalam penulisan skripsi. Masalahnya adalah tentang berpikir akademis sebagaimana tercermin dalam pedoman skripsi. Pemikiran akademis dalam penulisan skripsi dipandu oleh pedoman penulisan yang diterbitkan oleh institusi terkait. Kasus dalam penelitian ini adalah suatu pedoman skripsi praktik seni dalam suatu program studi seni rupa. Dalam buku ini tidak ada penjelasan eksplisit tentang aspek metode dan analisis. Padahal kedua aspek ini justru merupakan inti dari pemikiran akademis, yaitu pemikiran berbasis penelitian. Fakta ini mendorong studi model penulisan skripsi praktik seni, terutama dalam aspek metode dan analisis. Studi ini menerapkan pendekatan Penelitian dan Pengembangan (R\&D) dengan metode campuran. Model ini mengusulkan tipologi penelitian seni Teikmanis, seperti practiceled research, research-led practice, dan artistic research. Selain itu juga mengadaptasi struktur pendidikan seni Barrett, yang terdiri dari aspek konseptual, operasional, dan sintesis. Kesimpulan dari penelitian ini menunjukkan bahwa para partisipan dapat menyusun skripsi berdasarkan model ini.

Kata Kunci: penulisan skripsi, praktik seni, analisis, buku pedoman

\section{INTRODUCTION}

This study intends to present the reasoning, besides offering consideration to improve the quality of academic thinking for undergraduate art practice students, especially in thesis writing. Thesis in this paper is a research report texts, side by side with art products, and both are the learning outcomes of the academic art 
practitioner. These are common a requirement for art practice students of higher education in Indonesia. Undergraduate education standards in Indonesia are preparing students to be intellectuals and/or scientists who are civilized, able to enter and/or create a business, and able develop themselves to be professional (Indonesia Law of Higher Education act 12 of 2012 article 8 paragraph 2). In art scholarship, these standards are achieved through the ability to create works of art and compile research reports. The problem in this study is focused on the writing guidelines for research reports or so-called thesis that meet intellectual and/or scientific standards in the arts field.

The thesis is generally written based on guidelines published by the local institution. In the guidelines set the order of parts or writing systematic that describes academic thinking patterns. Regardless of the deepness of thesis content produced by each student, by complying with the guidelines, students enter into academic thinking patterns. That is, the quality of academic thinking reflected in the thesis is more or less depends on the quality of the guidelines. In other words, thesis guidelines also determine the quality of students' academic thinking who take thesis.

Higher education institutions in Indonesia have their writing guidelines. For some examples, The Thesis Guidelines 2016 by the Faculty of Cultural Studies, Universitas Brawijaya, The Final Assignment Guidelines 2015 by ISI Surakarta, and The Guidelines for Final Assignment 2019 by ISI Yogyakarta, these all have differences chaptering. Nevertheless, there are the same research fit aspects in these three examples, namely methods, and analysis or discussion. According to Creswell (2010), the research fit entails five aspects: the research paradigm- the research methodologies; ontology- the knowledge of the research; epistemology- the way the research knowledge is driven; axiology- the value of the research knowledge; and rhetoric- how the research knowledge (Askarzai, 2017).

The case in this study is based on guidelines of thesis writing published by an art study program, for which there are no sections of methods and analysis or discussion. These sections are precisely the essence of research, namely the use of high-order thinking skills in connecting data, theories, concepts, and researchers' experiences towards problem-solving. This essence is indeed slightly higher than the standard research level of the bachelor as Borgdoff (2013) mentions, that bachelor's curriculum teaches elementary research skills like argumentation, information, communication and presentation skills. This case prompted the question of how the thesis writing model on an art practice that meets the academic thinking aspects.

This study is an effort to find solutions to these weaknesses, it is to construct a thesis writing model of art practice that meet the aspects of academic thinking. The benefits of this study for academics is as an offer of discussion about art 
practice research. Especially for art practice students, this study is useful for improving the quality of academic thinking. For the arts educational institutions, this research is useful as a topic of discussion to improve the quality of thesis guidelines.

This study is considered essential especially for pragmatic reasons, it is because the guidelines which are the case in this study are being used by students in related institutions. Its weakness has been running. The results of this study can be considered as input to revise the guidelines. It is also important because it correlates with the prolonged debate at postgraduate degree; it is possible because the underside is not well organized yet.

Limitation of the study is focused on aspects of the method and analysis because the case in the guidelines lies in both aspects. Philosophy of art, aesthetic principles, and art education, in general, are not covered in this study. Besides, the data in this study were taken from a particular higher education institution, so it tends to exclusively apply to this institution. The conclusion in this study is also limited to solving this case. The next limitation related to the students in undergoing try out have not reached the discussion aspects yet, so this paper only revealed the method aspects.

Oxford English Dictionary has defined research as 'the systematic investigation into and study of materials and sources to establish facts and reach new conclusions'. Research in Merriam Webster Dictionary is described as 'the investigation or experimentation aimed at the discovery and interpretation of facts, revision of accepted theories or laws in the light of new facts, or practical application of such new or revised theories or laws'. Research on the model aims to be applied, so the definition follows the OECD (2015) applied research, is an original investigation undertaken to acquire new knowledge; it is, however, directed primarily towards a specific, practical aim or objective. In many cases, artistic research can be understood as an interdisciplinary and transdisciplinary activity and the different inter- or transdisciplinary entwinements lead to different types of artistic research (Arlander, 2016).

Art can be said to be the only system of knowledge which, when incorporated into the academic system, immediately creates prolonged problems. While research in other disciplines is relatively coherent with the limitations of the academic system, art does not. There is always a conflict of interest between the subjectivity in art and the objectivity in the academic system. There is even a view that this conflict cannot be bridged. "No bridge can be built to connect them, but some kinds of jump and intercourse are possible. Attaching the artworks to the presentation is an attempt to continue and share this intercourse. If readers find the artwork samples unhelpful, they should just skip them and focus on the text" (Mäki, 2014). This is a contextual opinion, which gives space for each interest according 
to the context. Unlike the case with the opinion that the artistic research becomes capable of pushing the future university to understand more deeply how to live on the planet we inhabit, rather than one we produce in our image (Butt, 2017). This opinion emphasizes the importance of art that contributes to academic interests. In the context of academic improvement, it is necessary to quote the opinion of Gray and Malins (2004) who consider academic research to be the best mechanism to raise awareness of critical and contextual issues of practice, to analyse and interpret ideas, and to develop new creative and cultural strategies based on rigorous evidence and research experience.

The issues of art-related research in higher education began to be debated in Christopher Fryling's paper (1993). Fryling categorizes art-related research into art, research through art, research for art. The first category is research in the art that relies on cognitive work, such as art history research, aesthetics, and art reviews from various theoretical perspectives. The output is written text. The second category is research in certain aspects of practising arts and is simultaneously communicated in writing, which means cognitional and expressional works. For instance, material and tools research, techniques research, creative development, action research, which all of the outputs are written text and art product. The latter category views the practice of art itself as a form of research, merely expressional, and the output is artifact. Of the three categories, Fryling tends to expressional works as the essence of art practice and offers research activities as an introduction to academic practice that should not be avoided. The term art practice research in this study, refer to Fryling's category, thus included in research through art.

Categorization of research into art, and research through art have clear, and commonly practiced in higher education. The debates arose primarily due to the third category that forced into the second category and generates understandings overlap. Opinion on the one side, for example, statement of Julian Klein (2017): "art without research just as equally dispenses of its essential foundation as does science without research". In the other side, for instance, Rae Earnshaw's (2016) quote about research type which the output is an artefact: "this area is less easy to evaluate in terms of possible academic outcomes and deliverables". Another statement made the debates go increasingly boisterous, such as Rubidge's (2005) in Mateus-Berr (2013) distinction of research for art into three types: practice-based research, practice-led research, dan practice as research. The first term is research that tests pre-formulated questions derived from artistic practice; the artist is the researcher. The second is research using the practice to research practice itself. The latter term seems to be equated with the first one, frequently used as an umbrella term for academic research which incorporates artistic practice as a 'research methodology.' This study leaves these debates and goes straight into 'research through art'. 
Teikmanis in "Typology of Research" (2013) has guided the understanding of various terms in art-related research. Based on the debate between research and art practical work, he compiled art researches into six types: academic research, practice-led research, research-led practice, design research, art-based research, and artistic research. These types are distinguished based on five aspects: the relationship between research and practice, subjective relations, research objects, types of produced knowledge, and research output. By comparing all aspects, there is similarity between research-led practice and design research. Both are only different in the form of work, artwork and design object so that in this study is integrated into research-led practice type. If we look at aspects of research output, there are three types that outputs are written text and artwork or design, namely practice-led research, research-led practice, and artistic research. Since this paper is for artwork and written text outputs then these three types as shown in the following table are further used as references.

Table 1. Types of art practice research.

Source: Teikmanis 2013, p. 163

\begin{tabular}{|c|c|c|c|c|c|}
\hline $\begin{array}{l}\text { Research } \\
\text { types }\end{array}$ & $\begin{array}{l}\text { The Relation } \\
\text { between } \\
\text { research and } \\
\text { practice }\end{array}$ & $\begin{array}{l}\text { Subjective } \\
\text { relations }\end{array}$ & $\begin{array}{c}\text { Research } \\
\text { object or } \\
\text { objects }\end{array}$ & $\begin{array}{c}\text { Types of } \\
\text { produced } \\
\text { knowledge }\end{array}$ & $\begin{array}{c}\text { Research } \\
\text { output }\end{array}$ \\
\hline $\begin{array}{l}\text { Practice-led } \\
\text { research }\end{array}$ & $\begin{array}{l}\text { Research is } \\
\text { based on } \\
\text { practice }\end{array}$ & $\begin{array}{l}\text { Author of } \\
\text { artwork = } \\
\text { researcher }\end{array}$ & $\begin{array}{l}\text { Artwork(s) } \\
\text { produced by } \\
\text { the researcher }\end{array}$ & $\begin{array}{l}\text { Artwork(s) and } \\
\text { documentation of } \\
\text { its production }\end{array}$ & $\begin{array}{l}\text { Artwork } \\
\text { and text }\end{array}$ \\
\hline $\begin{array}{l}\text { Research- } \\
\text { led practice }\end{array}$ & $\begin{array}{c}\text { The practice is } \\
\text { based on } \\
\text { research }\end{array}$ & $\begin{array}{c}\text { Researcher }= \\
\text { author of the } \\
\text { artwork }\end{array}$ & $\begin{array}{l}\text { Production of } \\
\text { artwork and } \\
\text { new } \\
\text { knowledge }\end{array}$ & $\begin{array}{c}\text { New } \\
\text { technological } \\
\text { solutions, } \\
\text { methods and } \\
\text { theories }\end{array}$ & $\begin{array}{l}\text { Artwork or } \\
\text { design } \\
\text { object and } \\
\text { text }\end{array}$ \\
\hline $\begin{array}{l}\text { Artistic } \\
\text { research }\end{array}$ & $\begin{array}{l}\text { Practice and } \\
\text { research are } \\
\text { inseparable }\end{array}$ & $\begin{array}{l}\text { Author of } \\
\text { artwork = } \\
\text { researcher }\end{array}$ & $\begin{array}{l}\text { Artistic } \\
\text { practice }\end{array}$ & $\begin{array}{l}\text { Artwork, ideas, } \\
\text { and theories }\end{array}$ & $\begin{array}{l}\text { Artwork } \\
\text { and text }\end{array}$ \\
\hline
\end{tabular}

\section{MATERIALS AND METHOD}

\section{Research Design}

This research implements a quantitative-qualitative approach, that is to arrange a thesis writing model which is validated by the experts quantifiably, and is qualitatively tried out on participant students. The experts and students are representing their self exclusively. The method is the Research and Development ( $\mathrm{R}$ and $\mathrm{D}$ ), where the definitions according to OECD, comprise creative and 
systematic work undertaken to increase the stock of knowledge - including knowledge of humankind, culture and society - and to devise new applications of available knowledge. In this study is an academic writing model. This method's procedure includes the stages of designing the model, validation, try out, implementation.

Data are expert and student opinions. The model is displayed in the Likert Scale adaptation format. It was validated by three experts, each representing the fields of fine arts, design and crafts. Validation results were quantified and interpreted as an academic value. After the model was revised based on the validation results, then trialled on the three students participating in the final project of art practice. Each student representing the fields of fine arts, design, and crafts.

The models for chapters III and IV is presented in a tabulation consist of indicators column, and agreement scale columns. Total indicators are 28 items, and the agreement on a scale of 4: disagree, quite agree, agree, strongly agree. The score of each item and validator are calculated by the formula: validator's score divided by the maximum score multiplied by 100 percent. The total score is interpreted into the range of academically values as follows: $60-69=$ less academic; $70-79=$ quite academic; 80-89 = academic; $90-100=$ strongly academic.

Data on student opinions were captured through open interviews. The topics of the interview emphasize experience in determining the choice of the final project idea and experience in practicing the model. Opinion on the first topic is needed to detect a student's mindset pattern, to correlate its tendencies with Teikmanis' types of research. Opinions on the second topic are needed for the model revision.

\section{Model Design on the Thesis Writing}

Aspects of the method described in chapter III. The instrument consists of 16 indicators. The number of items is relatively large because it accommodates the indicators for three fields of arts. This section contains the structure of art practice methods. All aspects of the method are shown in the following table.

Table 2. Art Practice Methods: Design of art practice methods. Source: Moerdisuroso \& Kherid, 2019

\section{A. Design of art practice methods}

1. Method approaches and research types

\begin{tabular}{lll}
\hline Field of art & Method approach & Type of research \\
\hline Fine art & qualitative: descriptive-qualitative & research-led practice \\
& or grounded research & $\begin{array}{l}\text { practice-led research } \\
\text { artistic research }\end{array}$ \\
Design & quantitative-qualitative: & research-led practice \\
& practice-led research
\end{tabular}

research, action research 


$\begin{array}{lll}\text { Craft } & \text { quantitative-qualitative: } & \text { research-led practice } \\ \text { development research, applied } & \text { practice-led research } \\ & \text { research, action research } & \text { artistic research }\end{array}$

2. Sources and types of data

\begin{tabular}{|c|c|c|c|}
\hline \multirow{2}{*}{ Data sources } & \multicolumn{3}{|c|}{ Type of data } \\
\hline & Conceptual & Visual & Operational \\
\hline $\begin{array}{l}\text { apprenticeship } \\
\text { (practitioner's } \\
\text { property) }\end{array}$ & $\begin{array}{l}\text { opinion, text, } \\
\text { event }\end{array}$ & $\begin{array}{l}\text { original works of } \\
\text { art, sketch, dummy, } \\
\text { mock-up, shop } \\
\text { drawing, } \\
\text { visual archives }\end{array}$ & $\begin{array}{l}\text { working process, } \\
\text { exploration process } \\
\text { materials, tools and } \\
\text { techniques, } \\
\text { studio facilities, }\end{array}$ \\
\hline $\begin{array}{l}\text { student's art } \\
\text { practice process } \\
\text { and products }\end{array}$ & oninion & $\begin{array}{l}\text { exploration pieces, } \\
\text { sketch, dummy, } \\
\text { mock-up, shop } \\
\text { drawing, } \\
\text { finished work of art, } \\
\text { design object, craft } \\
\text { object } \\
\text { opinion }\end{array}$ & $\begin{array}{l}\text { working process, } \\
\text { materials, tools and } \\
\text { techniques, } \\
\text { studio facilities }\end{array}$ \\
\hline
\end{tabular}

Table 3. Art practice methods: Data collection. Source: Moerdisuroso \& Kherid, 2019

\section{B. Data collection}

\begin{tabular}{|c|c|}
\hline Types of Data & Data collection techniques \\
\hline opinion & interview, questioner \\
\hline text & resume, quote \\
\hline event & logbook /field notes \\
\hline $\begin{array}{l}\text { exploration pieces, sketch, dummy, mock-up, } \\
\text { shop drawing, finished work of art, design } \\
\text { object, craft object, visual archives }\end{array}$ & photo/video recording \\
\hline $\begin{array}{l}\text { working process, } \\
\text { exploration process }\end{array}$ & $\begin{array}{l}\text { logbook /field notes, photo/video } \\
\text { recording }\end{array}$ \\
\hline $\begin{array}{l}\text { materials, tools and techniques, } \\
\text { studio facilities }\end{array}$ & $\begin{array}{l}\text { observation, check-list, photo/video } \\
\text { recording }\end{array}$ \\
\hline
\end{tabular}

Notes:

1. Apprenticeship data: resource person profiles, place and time of apprenticeship, data collection techniques

2. Expert/user data: expert/user profiles, place and time to collect, data collection techniques 
Table 4. Art practice methods: data presentation and analysis techniques. Source: Moerdisuroso, 2019

C. Techniques for presenting and analyzing data

1. Steps in presenting data

The steps in presenting data are a description of the plan to classify various types of data on apprenticeship, the process and products of art practice, as well as the forms of their appearance, in the form of tables, schemes, text box, and descriptions of each group of data.

2. Data analysis steps

The data analysis steps are an explanation of the discussion design of the data that has been presented previously. The design of the discussion must be correlated with the theoretical foundation and aspects of the concept of creation.

The results and discussion are described in chapter IV. The model in this section contains the practice of presenting data from various sources. This section also contains guidance in analysing the correlation of data from various sources with the theoretical foundation towards verifying the authenticity of creation concept aspects. The indicators are 12 items, shown in the following table.

\section{Table 5. Results and discussion}

\section{Source: Moerdisuroso \& Kherid, 2019}

\section{A. Results}

1. The results contain the presentation of data obtained from the processes and products of art practice as designed in Chapter III.

2. Data is grouped, tabulated, and described based on activities according to the fields of fine art, design, or craft.

3. Data groups include: results of apprenticeships, process and products of student's art practice, expert/user opinion.

4. The results of the apprenticeships consist of: the creation concept of resource person, the characteristics of the products, the process of art practice, studio facilities, and the elaboration of the results of the apprenticeship.

5. The process and products of student's art practice, market studies, preliminary designs, model designs, user opinions (only for the field of design and crafts), expert's opinions (only for the field of fine art), and the photograph of all works created.

6. User opinions are specific to the field of design and craft, related to studies of needs, responses to initial designs, and responses to model designs.

7. Expert opinion is the response, assessment and suggestion of an art expert to a student's artwork.

\section{B. Discussion}

1. In principle, this section is an implementation of the steps of data analysis. The analysis is oriented to confirm the authenticity of the concept of creation. The 
analytical framework can be based on the structure of the art (conceptual, visual, and operational aspects), or follows the theoretical foundation.

2. The discussion of conceptual aspects consists of breaking down the data of conceptual aspects of students, which are compared with the data group of conceptual aspects from all sources (apprenticeship sources, expert or user opinions), and practice references, and referring to the theoretical foundation. The discussion is oriented to prove the authenticity of the conceptual aspects of students. This discussion pattern is also used in the discussion of visual and operational aspects.

\section{RESULTS}

\section{Data of Experts Opinion}

Experts opinions are the validation results. Validator I (V-1) is a design educator, V-2 is craft educator, and V-3 is a fine art educator. The values of the model given from each validator are 90.8; 94.6; 94.6. All three gave values greater than 90 , is interpreted strongly academic. The indicator item that has the lowest scores (75.0) are interpreted to be quite academic, given only two items, one each for chapters III and IV as shown in the following table.

Table 6. The items on the lowest score. Source: Moerdisuroso \& Kherid, 2019

\begin{tabular}{|c|c|c|c|c|c|c|c|}
\hline NO & Indicators & $V-1$ & $\mathrm{~V}-2$ & $V-3$ & $\Sigma \mathbf{n}$ & $\Sigma \mathbf{V}$ & Interpretation \\
\hline A. & Chaper III & & & & & & \\
\hline 4 & $\begin{array}{l}\text { The design of quantitative-based creation } \\
\text { methods tends to resemble the methods of } \\
\text { development research, applied research, and } \\
\text { action research. }\end{array}$ & 3 & 3 & 3 & 9 & 75,0 & $\begin{array}{l}\text { quite } \\
\text { academic }\end{array}$ \\
\hline B. & Chaper IV & & & & & & \\
\hline 20 & $\begin{array}{l}\text { Data groups include: results of } \\
\text { apprenticeship, market study results, } \\
\text { preliminary designs, model designs, user } \\
\text { opinions (only for design and craft), expert } \\
\text { opinions (only for fine art), and all of the } \\
\text { finished product photographs. }\end{array}$ & 3 & 3 & 3 & 9 & 75,0 & $\begin{array}{l}\text { quite } \\
\text { academic }\end{array}$ \\
\hline
\end{tabular}

The instrument sheet provides a validator's notes. All three validators write notes with different intensities. V-1 gives the highest intensity note. V-1 notes emphasize that design methods take precedence, and suggests that the research process be shortened so that it does not have an impact on creative work. V-2 notes contain the affirmation of the majority of answers strongly agree; only 5 items were hesitant to be strongly agreed. V-3 notes are only a correction to the answers itself. 


\section{Data of Students Opinion}

The participant that tested this model consist of 3 students who were attending the art practice thesis seminar. Each student chooses fine art, design, and craft. Thesis in fine art entitled "Reflections on Asocial Behaviour Due to the Effects of Social Media in Contemporary Art". The field of design makes the title "Idealism of Millennial Generation Students in Comic Book". The craft field uses the title "Sebira Island Environment as an Inspiration on Handmade Batik Ornaments with Natural Dyes from Mangrove Tree Bark (Rhizophora Stylosa)".

Students opinion is focused on practicing the model Also opinions about the process of determining the final project ideas. In general, the three students stated their support with the model. According to them when carrying out apprenticeships also carry out activities as stated in the model, but it is less direct. They stated the model had directed the writing of the entire apprenticeship and exploration process. Design and craft students stated that the method in the model includes the design method already. The fine art student commented on the difficulty to find the experts and to ask the opinions as required. The three students shared the same opinion about the hassle of having to record all activities in the final project process. Until this study was written, the three students had not yet reached the stage of writing the discussion, so its data had not been obtained yet.

Opinions about the process of determining the final project ideas, design student told his experiences as activists: "Since in high school I like to join organizations and adventures. At the early, on campus, I actively participated in the student association of study programs, continue to get acquainted with student organizations in the faculty, until universities. I do not join parties, or other organizations, only in student affairs. So I never wanted to take to the street by order. We move only when there are troublesome government policies. I want to share this idealism with my juniors through comic stories."

Craft student tells the following experiences: "I once travelled to Sebira Island in the Thousand Islands. This is the farthest from Jakarta. People rarely come here. Many Bugisese, Madurese, Minangese. Men wear a sarong. They eat anchovies, lots of them here. There is a tower from the colonial era. The beach is full of mangrove trees. The colours are different. I take the skin, scribble on the shirt, the sap is imprinted. So thinking about making batik. The skin is pounded, boiled. Different colours of trees also result in fabric. The ornaments are taken from what is here, tower, sarongs, anchovies."

Fine art students tend to be quiet, but he said more regularly than the two students above. His experience related to the final project is told as follows: "I use to addict an online game. All-day in front of the computer. Even if I leave, my mind continues to be overshadowed by the game. So I cannot focus on me, even lazy to 
meet with anyone. I want to express this experience with installation art. I want to convey the message through material objects and space characteristics."

\section{DISCUSSION}

The opinions of three experts on the model, out of 28 indicators are interpreted as follows: strongly academic $=21$ items; academic $=$ five items, quite academic $=$ two items; less academic $=$ zero items. The acquisition of the lowest interpretation "quite academic" arises from items four and 20. For both items, the three validators give the same score which is three. Sentence point four is: "The design of quantitative-based creation methods tends to resemble the methods of development research, applied research, and action research". Concerning scoring three on point four, there is no validator providing notes. Factors causing the scoring the three (quite academic) were estimated because the use of the technical terms was not equipped with detailed explanation. These terms are correlated with the types of art-related research according to Fryling and Teikmanis. Research through art in Fryling's term is produced artefacts and written works. Development, applied and action research can be included in this term. Likewise, with the Teikmanis' term. Both research-led practices, practice-led research and artistic research is also produced the same things. One of which can be chosen to be associated with one of development, applied or action research. These three forms of research have similarities as research to produce something tangible, as well as in art practice research.

Other indicators that have low score is point 20, with the sentence: "Data groups include: apprenticeship, market study, preliminary designs, model designs, user opinions (only for design and crafts), expert opinion (only for fine art), and photos of all products of art practice. There are only V-1 notes to this item, that is "add product and designers reference studies". About this note, it can be stated that reference study activities are not placed in this chapter, because it is not classified as data. Based on this discussion, it seems that there are no significant deficiencies so that the model can proceed to the tryout phase.

Model try out generates student opinion data. The data of the three students showed a positive tendency, especially related to the methods (chapter III). It means designing the methods, determining the techniques and instruments of data collection, and planning the techniques of presentation, and analysis of data can be done by students of art practice. The ability to carry out all aspects of the method indicate students are applied a high order thinking. In Bloom's taxonomic revision (Anderson et al., 2001) low to high levels of cognition include: remember, understand, apply, evaluate, create. The last three are classified as high order thinking. To Anderson, all cognitive thinking relate to four levels of knowledge: factual, conceptual, procedural, and metacognitive. Refer to this taxonomy, 
students' ability in compiling methods are classified as procedural knowledge. Besides, according to the concept of creation structure which includes conceptual, visual, and operational aspects, students show their ability to describe the data specifications of each aspect.

Student experience in determining the idea of the final project can be correlated with Teikmanis' three types of art-related research. Although all students in the try-out have received an explanation of these types, and can consciously choose, they still need to be confirmed. By observing the flow of his experience can be detected trends in the type of art research.

Opinions of design student describe the experiences as activists. He explains this dominantly than the experience of making comics. By Barrett's term, the emphasize for his research is the conceptual aspect. This means that although it is not carried out in a disciplined manner, students have undergone research. Their own experiences as objects of research. Research results later developed into a storyboard, and then created a comic book. In simple terms, the sequences describe research-led practice from the conceptual aspect. This integration between art practice and research is in line with Graeme Sullivan (2004), is aimed to investigate how knowledge is created in the process of making art. Research in the art, therefore, asks questions about the processes and products of artistic knowledge. To do this the artist is both the researcher and the object of study.

The flow of experience above is almost the same as the experience of craft student. Starting an interested in the operational aspect, it is the experience of exploring mangrove bark material and its visual effects. Followed by the exploration of objects and events in the Sebira Island environment as an inspiration of batik ornaments. The practice of making batik is only possible after all exploration is considered complete. This pattern is in line with research-led practice from the operational aspect dominantly.

In undergoing the final project of art practice, a fine arts student, such as design student, also rely on their subjective experience. He felt asocial. In artistic activities, he tends to interact first with various materials and spaces possibilities whose characteristics are considered in line with the message to be expressed. This artistic encouragement is relatively difficult to plan and tends to be done by trial and error. It means the work sequence of this student tends to be classified as practice-led or artistic research and dominantly from the visual aspect. 


\section{CONCLUSION}

This study departs from the thesis guidelines for art practices that do not explicitly state the method and analysis aspects. The scope of research, methods, data, and analysis then is based on the question of how the thesis writing model of art practice. For this reason, a series of research has been carried out with the R \& D method, in which stages: the model design has been prepared, tested for readability, validated by experts, produced the model, and tested on students. Based on the entire research process the following conclusions are obtained:

1. The academic principle in art practice is the skill of creating works of art that interacts with the ability to build and confirm the concept of creation through research procedures, and the ability to communicate in writing according to the academic writing system.

2. Art practice research models that meet academic rules consist of three possible types: practice-led research, research-led practice, and artistic research, which can be correlated with quantitative, qualitative, or mixed approaches. The selection of research types by students is subjective, depending on the tendency of their thinking.

3. This thesis writing model of art practice, especially the method aspect which requires high order thinking can be implemented by students under research discipline relatively.

\section{REFERENCES}

Adisukma, Wisnu., Achmad Sjafi'i, Sunarmi, et al. (2015). "Panduan Tugas Akhir Seni Rupa dan Desain”. Institut Seni Indonesia Surakarta, Indonesia.

Anderson, Lorin W., David R. Krathwohl, Peter W. Airasian, Kathleen A. Cruikshank, Richard E. Mayer, Paul R. Pintrich, James Raths, Merlin C. Wittrock (2001). A Taxonomy for Learning, Teaching, and Assessing: A Revision of Bloom's Taxonomy of Educational Objectives. A Bridge Edition. United States: Addison Wesley Longman. ISBN 0-8013-1903-X

Arlander, Annette. (2017). Artistic Research for Speculative Practice. Journal for Artistic Research. ISSN 2235-0225. Accessed on 16 May 2020 from https://doi.org/10.22501/jarnet.0001

Askarzai, Walied., Bhuvan Unhelkasr. (2017). Research Methodologies: An Extensive Overviews. IJSRM International Journal of Science and Research Methodologies Vol. 6, Issue 4, June 2017. http://ijsrm.humanjournals.com/wp-content/uploads/2017/07/3.Dr_.Walied-ASKARZAI-Bhuvan-Unhelkar.pdf 
Barrett, Maurice. (1982). Art Education, Strategy for Course Design. London: Heinemann Educational Books.

Borgdorff, Henk. (2013). "A brief survey of current debates on the concepts and practices of research in the arts". In Mick Wilson and Schelte van Ruiten (eds.) Handbook for Artistic Research Education. SHARE, Step-Change for Higher Arts Research and Education. Amsterdam: Elia. ISBN 978-90810357-0-5. Retrieved on May 2017 from http://www.sharenetwork.eu/resources/share-handbook

Borgdorff, Henk. (2016). Buku Pedoman Penulisan Skripsi. Malang: Fakultas Ilmu Budaya, Universitas Brawijaya.

Butt, Danny. (2017). Artistic Research in the Future Academy. Bristol, UK: Intellect Books.

Earnshaw, Rae. (2016). Research and Development in Art, Design, and Creativity. UK: Springer. DOI 10.1007/978-3-319-33005-1

Fryling, Christopher. (1993). "Research in art and design". Royal College of Art Research Paper Vol. 1. No. 1. 1993/4. London: Royal College of Art. ISBN 187417555 1. Retrieved on 25 July 2019 from http://researchonline.rca.ac.uk/384/3/frayling_research_in_art_and_design _1993.pdf

Gray, Carole, Julian Malins. (2016). Visualizing Research: A Guide to the Research Process of Art and Design. New York, USA: Routledge.

Klein, Julian. (2017). What is artistic research? Journal for Artistic Research. ISSN 2235-0225. Accessed on 13 August 2019 from https://doi.org/10.22501/jarnet.0004

Mäki, Teemu. (2014). Art and Research Colliding. Journal for Artistic Research. ISSN 2235-0225. (2014) Accessed on 16 May 2020 from https://www.researchcatalogue.net/view/49919/49920/0/0

Mateus-Berr, Ruth. (2013). "Habits' within arts and design-based research". In Mick Wilson and Schelte van Ruiten (eds.) Handbook for Artistic Research Education. SHARE, Step-Change for Higher Arts Research and Education. Amsterdam: Elia. ISBN 978-90-810357-0-5. Retrieved on July 2019 from http://www.sharenetwork.eu/resources/share-handbook

Merriam Webster Dictionary. Accessed on 16 August 2019 from https://www.merriam-webster.com/dictionary/research.

OECD (2015). "Concepts and definitions for identifying R\&D”, in Frascati Manuao 2015: Guidelines for Collecting and Reporting Data on Research and Experimental Development. Paris: OECD Publishing. Retrieved on 25 July 2019 from http://dx.doi.org/10.1787/9789264239012-4-en

Oxford English Dictionary. Accessed from https://www.lexico.com/en/definition/research on 16 August 2019. 
(2019). Pedoman Pembimbingan Tugas Akhir Program Studi S-1 Seni Rupa Murni. Yogyakarta: Fakultas Seni Rupa, Institut Seni Indonesia.

Sullivan, Graeme. (2004). Studio art as a research practice. In Elliot W. Eisner and Michael D. Day (eds.) Handbook of Research and Policy in Art Education. New Jersey: Lawrence Erlbaum Associates Inc.

Teikmanis, Andris. (2013). Typology of research. In Mick Wilson and Schelte van Ruiten (eds.) Handbook for Artistic Research Education. SHARE, StepChange for Higher Arts Research and Education. Amsterdam: Elia. ISBN 978-90-810357-0-5. Retrieved on May 2019 from http://www.sharenetwork.eu/resources/share-handbook

Undang-undang Republik Indonesia Nomor 12 Tahun 2012 tentang Pendidikan Tinggi. Kementerian Hukum dan Hak Asasi Manusia Republik Indonesia, 10 Agustus 2012.

Wilson, Brent G. (1971). Evaluation of Learning in Art Education. In Bloom, B. T. Handbook on Formative and Summative Evaluation of Student Learning. New York, USA: McGraw-Hill Inc. 